各種自動抽出装置による法科学試料からの DNA 抽出について

藤井宏治，井口奨太，北山哲史，中原弘明，水野なつ子，関口和正

\author{
科学警察研究所 \\ 7277-0882 千葉県柏市柏の葉 6-3-1
}

\title{
DNA Extraction From Various Forensic Samples Using Automated Extraction Instruments.
}

\author{
Koji Fujii, Shota Inokuchi, Tetsushi Kitayama, Hiroaki Nakahara, \\ Natsuko Mizuno and Kazumasa Sekiguchi \\ National Research Institute of Police Science \\ 6-3-1, Kashiwanoha, Kashiwa, Chiba 277-0882, Japan
}

(Received 13 January 2011; accepted 8 June 2011)

We compared automated DNA extraction instruments of AutoMate Express, EZ1 Advanced XL, Maxwell 16 and QIAcube for forensic purpose. DNA was extracted from fresh bloodstains and fresh diluted bloodstains on cotton and denim, three 3-mm punches of FTA card containing buccal cells collected by EasiCollect, and head hair roots and shafts. The genomic and mitochondrial DNA was quantified by real-time PCR assay using D17Z1 locus and/or the C region of hyper variable region 1 (HV1). The extracted DNA was used to amplify 15 STR loci of Identifiler kit and/or the $\mathrm{A}$ and the $\mathrm{C}$ regions in HV1.

AutoMate Express tended to give the highest DNA concentration from all the samples except for FTA cards and hair roots. Full STR profiles were obtained using all the instruments from bloodstains on cotton and denim, FTA cards and hair roots. Out of the 15 diluted bloodstain samples on cotton and denim, full STR profiles were obtained from 14 and 15 samples for AutoMate Express, 11 and 14 samples for EZ1 Advanced XL, 0 and 6 samples for Maxwell 16, and 8 and 14 samples for QIAcube, respectively. When $20 \mu \mathrm{l}$ of the denim extract was concentrated and amplified with $1 \mathrm{ng}$ of 9947A DNA, PCR inhibition was slightly observed using AutoMate Express and Maxwell 16, but not observed when using EZ1 Advanced XL and QIAcube.

When the $\mathrm{A}$ and the $\mathrm{C}$ regions of HV1 were amplified using 2,000 copies of the hair root DNA extracted by all the instruments, positive bands were observed from almost all the samples. On the other hand, when 2,000 copies or less of the hair shaft DNA were amplified, the bands of the A region were weaker than those of the $\mathrm{C}$ region for all the instruments especially for AutoMate Express.

In conclusion, AutoMate Express and EZ1 Advanced XL are suitable for DNA 
extraction from forensic samples, since they are easier to operate than QIAcube is, and they give higher DNA yield than Maxwell 16 does.

Key words: Forensic, DNA, Automate DNA extraction instrument, STR typing, Mitochondrial DNA

\section{緒 言}

法科学試料からの DNA 抽出には，従来から用い られているフェノール・クロロホルム法に代わり， 抽出操作が簡便である DNA 抽出キットが用いられ るようになってきた ${ }^{1)}$. DNA 抽出キットによる DNA 抽出では, 試料溶解後の DNA 抽出操作に抒 いて, 試料の種類による違いが少ないため, 抽出操 作を自動化した装置やシステムが開発されてい る2,3).キアゲン製の BioRobot EZ1 は，磁気ビー ズ法を採用し，法科学試料に対応した DNA 抽出プ ロトコールを多数用意した自動抽出装置であ り4-6)，手作業による QIAamp DNA Investigator kit などの QIAamp 系のキットとともに，日本警察で 広く用いられている。この BioRobot EZ1 以外に, 法科学試料に対応したプロトコールを用意した自動 抽出装置としては，磁気ビーズ法の DNA IQ 系キ ットを自動化したプロメガ製の Maxwell 167) および カラム法の QIAamp 系キットを自動化したキアゲ ン製のQIAcubeが，それぞれ市販されている。ま た, 最近では, 磁気ビーズ法の PrepFiler forensic DNA extraction $\left.\mathrm{kit}^{8}\right)$ を自動化したアプライドバイ オシステムズ製の AutoMate Express が市販化され た. 本研究では, 比較的小規模の試料数（16試料以 下）を同時に処理し，かつ法科学試料用のキットや プロトコールを用意した自動抽出装置として，AutoMate Express, EZ1 Advanced XL, Maxwell 16打よ びQIAcube を用いて，実験的に作製した血痕（サ ラシ布), 希釈血痕 (サラシ布), 血痕 (デニム布), 希釈血痕 (デニム布), 口腔内細胞 (FTA カード), および毛根部から，DNA 抽出を行い，核 DNA の 定量，およびSTR 型検查について検討した。ま た, 毛幹部についても, これらの装置により DNA 抽出を行い, 毛根部からの抽出した DNA 溶液とと もに，ミトコンドリアDNAの定量，およびミトコ
ンドリア DNA 検査について検討した.

\section{材料および方法}

\section{1 実験材料}

実験内容について同意している成人男性 3 名（個 人\#01，個人\#02および個人\#03）から提供を受けた 血液, 口腔内細胞および毛髪を試料とした.

1.1 血痕（サラシ布）, 希釈血痕（サラシ布）, 血 痕（デニム布）および希釈血痕（デニム布）

血液は，採取後， $-80^{\circ} \mathrm{C}$ に保存していたものを用 いた。 血液の一部は, PBS (Phosphate buffered saline）で10倍に希釈し，希釈血液とした。サラシ 布，およびデニムで染色されたジーンズ（以下「デ 二厶布」という）を，大きさ約 $0.5 \mathrm{~cm} \times 0.5 \mathrm{~cm}$ に切 り取り, 血液 $3 \mu \mathrm{l}$ 打よび希釈血液 $3 \mu \mathrm{l}$ を付着させ た後, 室温で一夜放置して乾燥させた。各試料は, 実験に必要な個数を同時に作製し，1試料ごとに $1.5 \mathrm{ml}$ チューブに入れ，使用するまでー $80^{\circ} \mathrm{C} て ゙$ 保存 した。また，デニム由来の PCR 阻害の有無を確認 するため，試料を付着させない大きさ約 $0.5 \mathrm{~cm} \times$ $0.5 \mathrm{~cm}$ のデニム布を，実験に用いた。

\section{2 口腔内細胞（FTA カード）}

口腔内細胞は, EasiCollect（GEヘルスケア製） により9)，最低でも 3 時間の間隔をあけ，付属の説 明書10)にしたがって5 回ずつ採取し，得られた FTA カードは, 保存用シリカゲルパック（GEへ ルスケア製）とともに，FTA カード保護用ポーチ 大（FTA クラッシックカード用， GEヘルスケア 製）に入れ，数日間，室温で乾燥させた。乾燥させ た FTA カードは，ハリスマイクロパンチ（直径 3.0 $\mathrm{mm} ， \mathrm{GE}$ ヘルスケア製）を用いて，FTA カードの 中心から，放射遠心方向に 3 箇所連続でパンチして くり抜き，得られたディスク 3 枚を， $1.5 \mathrm{ml}$ チュー ブ 1 本に入れ， 1 回分の試料とした。このくり抜き を，1枚の FTA カードにつき，4 回繰り返し，4 種 
類の装置で 1 回ずつ使用するための試料を得た. 3 名分のFTA カード各 5 枚からは, 各装置用に，そ れぞれ計15回分の試料を得たことになる。これらの 試料は，使用するまでー $80^{\circ} \mathrm{C}$ で保存した.

\section{3 毛根部および毛幹部}

3 名分の抜去毛, 各 35 試料について, 毛根部約 5 $\mathrm{mm}$ ，および毛根側の毛幹部約 $20 \mathrm{~mm}$ を実験に用い た. 毛幹部の太さの平均值と標準偏差は, 個人\#01 のもので $89 \pm 17 \mu \mathrm{m}$, 個人\#02のもので $74 \pm 12 \mu \mathrm{m}$, および個人 $\# 03$ のもので $85 \pm 12 \mu \mathrm{m}$ であった. あら かじめ, 毛根部については滅菌水, 毛幹部について は 5\% Terg-A-zyme（アルコノックス製）および 滅菌水により，それぞれ，洗浄した。1名あたり， 35 試料の毛根部および毛幹部は，それぞれ， 7 試料 ずつをチューブ 5 本に分け，チューブ 1 本につき， QIAamp DNA Investigator kit（キアゲン製）に含 まれるATL buffer $630 \mu \mathrm{l}$ および $600 \mathrm{mAU} / \mathrm{ml}$ QIAgen proteinase $\mathrm{K} 70 \mu \mathrm{l}$, ならびに $1 \mathrm{M}$ DTT (Dithiothreitol, プロメガ製) $24.5 \mu \mathrm{l}$ 加え， $56^{\circ} \mathrm{C}$ で 1 時間処理した。得られた溶解液は, チューブ 1

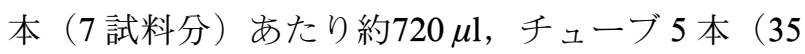

試料分）で計約 $3.6 \mathrm{ml}$ となるが，この35試料分の溶 解液は, よく混合した後, $100 \mu \mathrm{l}$ ずつ, チューブ35 本に分注し，使用するまで $-80^{\circ} \mathrm{C}$ で保存した。

\section{DNA 抽出}

4 種類の装置により, 3 名分の各試料について 5 試料ずつDNA 抽出を行った（Table 1).なお， EZ1 Advanced XL おちよび QIAcube では, DNA 抽 出に用いる溶解液の液量が，今回検討に用いたキッ トの場合，それぞれ，200 $\mu \mathrm{l}$ および $300 \mu \mathrm{l}$ に固定さ れて抢り, また, 血痕 (サラシ布), 希釈血痕 (サ ラシ布), 血痕（デニム布）, 希釈血痕（デニム布） 抢よび口腔内細胞（FTA カード）（以下，まとめて 「斑痕試料」という）では, 試料担体ごとに, 吸収 される液量が異なるため, 回収できなくなる量を考 慮し, 試料担体ごとに, 溶解液の液量を変えて, 試 料の溶出を行った.

\subsection{AutoMate Express (AME)}

AutoMate Express（アプライドバイオシステム ズ製，以下「AME」という）には, PrepFiler express forensic DNA extraction kit（アプライドバイ オシステムズ製）を用いた。斑痕資料は, PrepFil-

Table 1 Features of automated DNA extraction instruments used in this study.

\begin{tabular}{|c|c|c|c|c|}
\hline & AutoMate Express & EZ1 Advanced XL & Maxwell 16 & QIAcube \\
\hline $\begin{array}{l}\text { DNA extraction } \\
\text { method }\end{array}$ & Magnetic beads & Magnetic beads & Magnetic beads & Column \\
\hline $\begin{array}{l}\text { Maximum sample } \\
\text { number }\end{array}$ & 13 & 14 & 16 & 12 \\
\hline $\begin{array}{l}\text { Approximate } \\
\text { processing time }\end{array}$ & $28 \mathrm{~min}$. & $16 \mathrm{~min}$. & $30 \mathrm{~min}$. & $80 \mathrm{~min}$. \\
\hline $\begin{array}{l}\text { Preparation for } \\
\text { operation }\end{array}$ & Easy & Easy & Normal & Laborious \\
\hline Reagent & $\begin{array}{l}\text { Sealed in a cartridge } \\
\text { for each sample }\end{array}$ & $\begin{array}{l}\text { Sealed in a cartridge } \\
\text { for each sample }\end{array}$ & $\begin{array}{l}\text { Sealed in a cartridge } \\
\text { for each sample }\end{array}$ & Supplied in bottles ${ }^{\mathrm{b}}$ ) \\
\hline DNA elution & $50 \mu \mathrm{l}$ of TE buffer & $\begin{array}{l}40,50,100 \text { or } 200 \mu \mathrm{l} \text { of } \\
\text { TE buffer or Water. }\end{array}$ & $\begin{array}{l}25-50 \mu \text { l of Elution } \\
\text { buffer }^{\mathrm{c})}\end{array}$ & $\begin{array}{l}20-100 \mu 1 \text { in incre- } \\
\text { ments of } 10 \mu \mathrm{l} \text { of ATE } \\
\text { buffer or Water }\end{array}$ \\
\hline \multirow[t]{2}{*}{$\begin{array}{l}\text { Extraction kit }(\mathrm{s}) \text { for } \\
\text { forensic purpose }\end{array}$} & $\begin{array}{l}\text { PrepFiler Express } \\
\text { forensic DNA extrac- } \\
\text { tion kit }{ }^{\mathrm{d})}\end{array}$ & $\begin{array}{l}\text { EZ-1 DNA Investiga- } \\
\text { tor } \text { kit }^{\mathrm{d})}\end{array}$ & $\begin{array}{l}\text { DNA IQ casework } \\
\text { sample kit for Maxwell } \\
16^{\mathrm{d})}\end{array}$ & $\begin{array}{l}\text { QIAamp DNA } \\
\left.\text { Investigator kit }{ }^{d}\right)\end{array}$ \\
\hline & $\begin{array}{l}\text { PrepFiler Express BTA } \\
\text { forensic DNA extrac- } \\
\text { tion kit }\end{array}$ & & $\begin{array}{l}\text { DNA IQ reference } \\
\text { sample kit for Maxwell } \\
16\end{array}$ & \\
\hline
\end{tabular}

a): Time for sample lysis is not included.

b): The user needs to pour each of reagents from the bottle of the kit to the bottle of the instrument.

c): The volume can be determined continuously within $25-50 \mu \mathrm{l}$, since the elution buffer is manually transferred to the elution tube.

d): The extraction kit used in this study. 
er LySep column（キット付属）に入れ, PrepFiler lysis buffer（キット付属） $500 \mu \mathrm{l}$ および 1 M DTT 5 $\mu \mathrm{l}$ の混合液のうち $500 \mu \mathrm{l}$ を加え, $70^{\circ} \mathrm{C} て ゙ 40$ 分間処理 した後，このPrepFiler LySep columnを，6,000 g で 2 分間, 遠心分離して溶解液を回収し, DNA 抽 出に用いた。毛根部および毛幹部の溶解液 $100 \mu \mathrm{l}$ に は, PrepFiler lysis buffer $400 \mu \mathrm{l}$ 加え, DNA 抽出 に用いた。 DNA 抽出には, PF Express scriptを用 い, 最終的に, TE buffer $50 \mu \mathrm{l}$ で, DNA を抽出し た。

\section{2 EZ1 Advanced XL (EZ1 XL)}

EZ1 Advanced XL（キアゲン製，以下「EZ1 XL」 という)には, EZ1 DNA Investigator kit（キアゲ ン製）を用いた。斑痕試料には，2 倍希釈した G2 buffer（キット付属）を，血痕（サラシ布）および 希釈血痕（サラシ布）では $240 \mu \mathrm{l}$, 血痕（デニム布） および希釈血痕（デニム布）では $270 \mu \mathrm{l}$ ，ならびに 口腔内細胞 (FTA カード) では $210 \mu \mathrm{l}$ を加え, さ らに, $600 \mathrm{mAU} / \mathrm{ml}$ QIAgen proteinase $\mathrm{K}$ (キット 付属）を $10 \mu \mathrm{l}$ 加え, $56^{\circ} \mathrm{C} て ゙ 15$ 分間加熱した後, ピ ペットチップを用いて溶解液を $200 \mu \mathrm{l}$ 回収し,

DNA 抽出に用いた。毛根部および毛幹部の溶解液 $100 \mu \mathrm{l}$ には, QIAamp DNA Investigator kitに含ま れるATL buffer を $100 \mu$ l 加え, DNA 抽出に用い た. DNA 抽出には, Trace modeを用い, 最終的 に, 水50 $\mu \mathrm{l}$ で DNA を抽出した.

\subsection{Maxwell 16 (MW16)}

Maxwell 16 (プロメガ製，以下「MW16」という） には, DNA IQ casework sample kit for Maxwell 16 (プロメガ製) を用いた。斑痕試料には, Tissue and hair extraction kit (for use with DNA IQ, プロ メガ製）に含まれる Incubation buffer $190 \mu \mathrm{l}$ および $18 \mathrm{mg} / \mathrm{ml}$ Proteinase $\mathrm{K} 10 \mu \mathrm{l}$ を加え, $56^{\circ} \mathrm{C}$ で 1 時間 加熱した後, Lysis buffer (キット付属) を400 $\mu \mathrm{l}$ 加 え, ピペットチップを用いて, できるだけ液を回収 し, DNA 抽出に用いた。毛根部および毛幹部の溶 解液 $100 \mu \mathrm{l}$ には, Lysis buffer を400 $\mathrm{l}$ 加え, DNA 抽出に用いた。 DNA 抽出には, Forensic_LEV modeを用い，最終的に Elution buffer (キット付属) $50 \mu \mathrm{l}$ で DNA を抽出した.

\subsection{QIAcube (QC)}

QIAcube（キアゲン製，以下「QC」という）に は, QIAamp DNA Investigator kit（キアゲン製） を用いた。斑痕試料には，ATL buffer（キット付 属）を，血痕（サラシ布）抢よび希釈血痕（サラシ 布）では $330 \mu \mathrm{l}$, 血痕（デニム布）および希釈血痕 （デニム布）では $360 \mu \mathrm{l}$ ，ならび口腔内細胞（FTA カード）では $300 \mu \mathrm{l}$ 加え, さらに, $600 \mathrm{mAU} / \mathrm{ml}$ QIAgen proteinase K（キット付属）を20 $\mu \mathrm{l}$ 加え， $56^{\circ} \mathrm{C}$ で 1 時間加熱した後, ピペットチップを用い て, 溶解液を $300 \mu \mathrm{l}$ 回収し, DNA 抽出に用いた. 毛根部抢よび毛幹部の溶解液 $100 \mu \mathrm{l}$ には, ATL buffer $200 \mu \mathrm{l}$ 加え, DNA 抽出に用いた. DNA 抽 出には, QIAamp DNA Investigator kit_Forensic casework samples protocol を用い, 最終的に, 水50 $\mu \mathrm{l}$ でDNA を抽出した.

\section{3 核DNA およびミトコンドリアDNA の定量}

斑痕試料および毛根部から抽出した DNA 溶液 2 $\mu \mathrm{l}$ を用いて，D17Z1領域を用いた方法により，核 DNA を定量した ${ }^{11)}$ 。をた，毛根部および毛幹部か ら抽出した DNA 溶液 $2 \mu \mathrm{l}$ を用いて，ミトコンドリ ア DNAの HV1 領域 (Hyper variable region 1) に ある C 領域を用いた方法により，ミトコンドリア DNA を定量した ${ }^{12)}$ ・どちらの DNA 定量について も， SYBR premix Ex Taq（タカラバイオ製）掠よ び Thermal Cycler Dice Real Time System（タカラバ イオ製）を用いたリアルタイム PCR で行った。

\section{STR 型検査}

血痕 (サラシ布), 口腔内細胞 (FTA カード) お よび毛根部から抽出した DNA 溶液については，3 名分の各 5 試料のうち，それぞれ 1 試料から，ま た，希釈血痕 (サラシ布), 血痕（デニム布），希釈 血痕（デニム布）から抽出した DNA 溶液について は，3名分の各 5 試料すべてから, AmpFISTR Identifier kit（アプライドバイオシステムズ製）に より, PCR 増幅を行った ${ }^{13,14)}$. Identifier kit では, PCR 増幅の至適鋳型 DNA 量は $0.5 \sim 1 \mathrm{ng}{ }^{13,14)}$ であ るが，PCR 反応液に入れることができる DNA 溶 液は $10 \mu \mathrm{l}$ が上限であるため, 各試料の鋳型 DNA 量は，核 DNA の濃度が $0.1 \mathrm{ng} / \mu \mathrm{l}$ 以上のものにつ いては $1 \mathrm{ng}, 0.1 \mathrm{ng} / \mu \mathrm{l}$ 未満のものについては, 10 
$\mu \mathrm{l}$ を用いて, PCR 増幅した. 試料を付着させない デニム布から各装置により得られた抽出液 $9 \mu \mathrm{l}$ に， $1 \mathrm{ng} / \mu \mathrm{l}$ に希釈した9947A DNA（プロメガ製） $1 \mu \mathrm{l}$ を混合して，PCR 増幅した。ささらに，この抽 出液 $20 \mu \mathrm{l}$ を濃縮乾燥した後, Identifier kit に付属 の9947A DNA $(0.1 \mathrm{ng} / \mu \mathrm{l})$ を $10 \mu \mathrm{l}$ 加えて, PCR 増幅した。PCR 増幅産物は， 3130 XL Genetic Analyzer（アプライドバイオシステムズ製）で電気 泳動し, GeneMapper ID software 3.2.1（アプライ
ドバイオシステムズ製）で解析した。なお，DNA 型を判定する最小のピーク高は150 RFU （Relative fluorescent unit）とした ${ }^{13,14)}$.

\section{5 ミトコンドリア DNA 検査}

毛根部および毛幹部から抽出した DNA 溶液につ いて，ミトコンドリア DNA の HV1 領域にあるA 領域（約440塩基）および C 領域（約230塩基）を, 反応液 $25 \mu$ 1 中で PCR 増幅した ${ }^{15)}$. PCR 増幅に用 いる鋳型量は，ミトコンドリア DNAの濃度が500 (a) Bloodstain on cotton

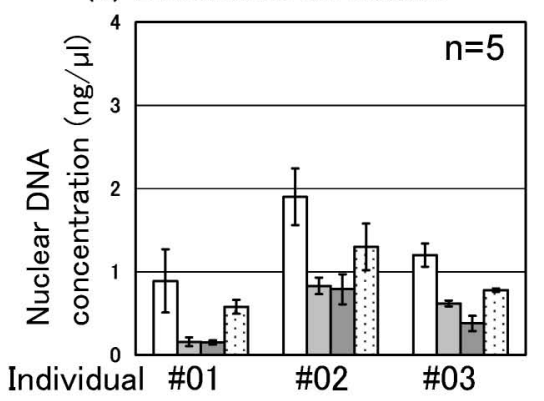

(c) Bloodstain on denim

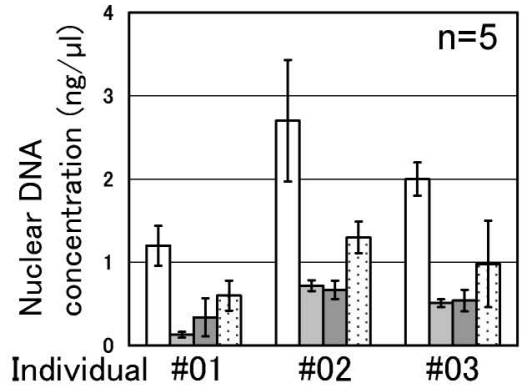

(e) Buccal cells on FTA card

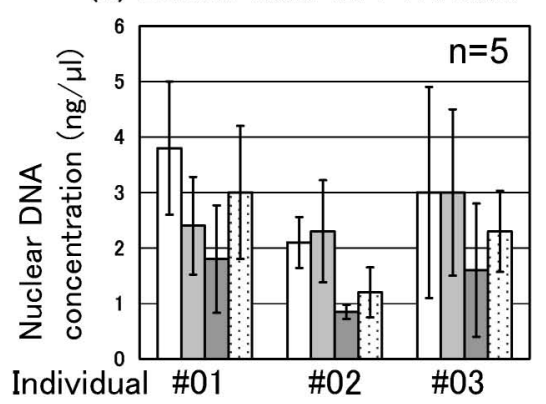

(b) Diluted bloodstain on cotton

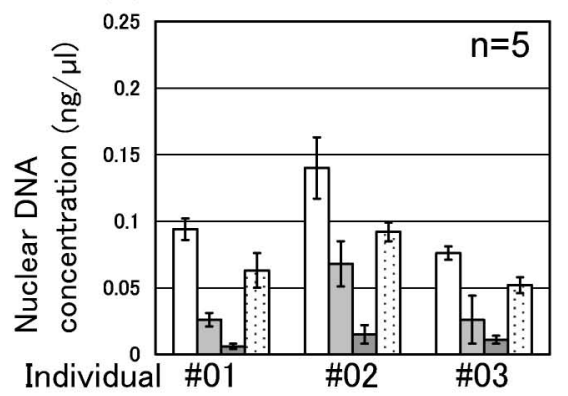

(d) Diluted bloodstain on denim

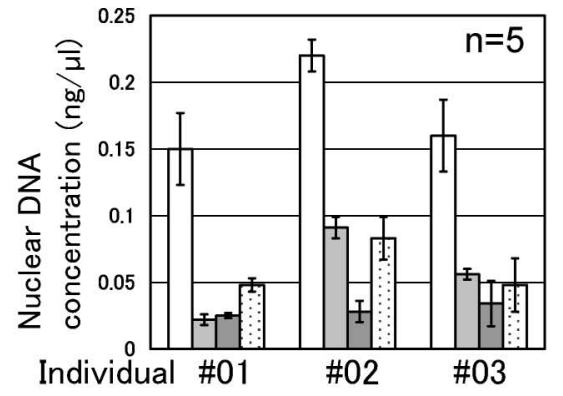

Fig. 1 The concentrations of nuclear DNA. DNA was obtained by automated extraction instruments from $3 \mu 1$ of bloodstain on cotton (a), $3 \mu \mathrm{l}$ of 10-time diluted bloodstain on cotton (b), $3 \mu \mathrm{l}$ of bloodstain on denim (c) , $3 \mu \mathrm{l}$ of 10-time diluted bloodstain on denim (d), and three 3-mm punches of FTA card containing buccal cells collected by EasiCollect (e). DNA was extracted by following the suppliers' instructions. DNA concentration was quantified by real-time PCR assay using human specific sequence of D17Z1 locus. The averages and standard deviations of the DNA concentrations are shown. 
copies/ $\mu$ 以上のものについては，2,000 copies を, また， 500 copies $/ \mu \mathrm{l}$ 未満のものについては， $4 \mu \mathrm{l}$ を 用いて, PCR 増幅した。得られた PCR 産物は, 2 \%アガロースゲルで泳動し，バンドの濃さを観察し た。 また， 3 名分の各 5 試料のうち，それぞれ 1 試 料について, HV1 領域の A 領域および HV2 領域 の D 領域を, さらに個人の塩基配列により必要な 場合には, HV1 領域の B 領域および C 領域, なら びに HV2 領域の E 領域を，上記と同じ鋳型量を用 いて PCR 増幅し, 得られた PCR 産物を精製後,

BigDye terminator v1.1 cycle sequencing kit (アプラ イドバイオシステムズ製）を用いてシーケンス反応 を行い, 3130 XL Genetic Analyzerにより電気泳動 し, Sequencing Analysis 5.3.1 (アプライドバイオ システムズ製）および Sequencher 4.7 （ジーンコー ド製）により塩基配列解析を行った.

\section{結 果}

1 血痕, 希釈血痕および口腔内細胞（FTA カー ド）からの DNA 抽出，ならびに STR 型検査

血痕（サラシ布），希橎血痕（サラシ布），血痕 （デニム布）および希釈血痕（デニム布）から，各 装置で抽出した DNA 溶液の核 DNA の定量值は,

AME, QC, EZ1 XL, MW16の順に低くなる傾向が観 察された。口腔内細胞（FTA カード）については,

MW16が，他の装置よりも若干，低い DNA 定量值 を示す傾向が観察されたものの，各装置間に大きな 差は観察されなかった（Fig. 1).

STR 型検査については，STR 型検査に十分な核 DNAの定量值が得られた血痕（サラシ布）および 口腔内細胞 (FTA カード) の試料については，い ずれの装置を用いても，すべての座位が検出され た。一方，希釈血痕（サラシ布）については，3名 分の計15試料について検査を行い, 全座位が検出さ れたのは, AMEでは 14試料, EZ1 XLでは11試

Table 2 Number of full STR profile(s) obtained from DNA solution extracted by automated extraction instruments.

\begin{tabular}{|c|c|c|c|c|c|c|}
\hline \multirow{2}{*}{ Individual } & \multicolumn{3}{|c|}{ Bloodstain on cotton $(n=1)$} & \multicolumn{3}{|c|}{ Diluted bloodstain on cotton $(n=5)$} \\
\hline & $\# 01$ & $\# 02$ & $\# 03$ & $\# 01$ & $\# 02$ & $\# 03$ \\
\hline AutoMate Express & 1 & 1 & 1 & 5 & $4(1)^{a)}$ & 5 \\
\hline EZ1 Advanced XL & 1 & 1 & 1 & 5 & $4(1)^{a)}$ & $2(1)^{a)}$ \\
\hline Maxwell 16 & 1 & 1 & 1 & 0 & $0(4)^{a)}$ & $0(1)^{a)}$ \\
\hline QIAcube & 1 & 1 & 1 & $\left.3(2)^{a}\right)$ & $2(3)^{a)}$ & $3(2)^{a)}$ \\
\hline \multirow{2}{*}{ Individual } & \multicolumn{3}{|c|}{ Bloodstain on denim $(n=5)$} & \multicolumn{3}{|c|}{ Diluted bloodstain on denim $(n=5)$} \\
\hline & $\# 01$ & $\# 02$ & $\# 03$ & $\# 01$ & $\# 02$ & $\# 03$ \\
\hline AutoMate Express & 5 & 5 & 5 & 5 & 5 & 5 \\
\hline EZ1 Advanced XL & 5 & 5 & 5 & $\left.4(1)^{a}\right)$ & 5 & 5 \\
\hline Maxwell 16 & 5 & 5 & 5 & $\left.2(3)^{a}\right)$ & $1(4)^{a)}$ & $\left.3(2)^{a}\right)$ \\
\hline QIAcube & 5 & 5 & 5 & 5 & 5 & $\left.4(1)^{a}\right)$ \\
\hline \multirow{2}{*}{ Individual } & \multicolumn{3}{|c|}{ Buccal cells on FTA card $(n=1)$} & \multicolumn{3}{|c|}{ Hair root $(n=1)$} \\
\hline & $\# 01$ & $\# 02$ & $\# 03$ & $\# 01$ & $\# 02$ & $\# 03$ \\
\hline AutoMate Express & 1 & 1 & 1 & 1 & 1 & 1 \\
\hline EZ1 Advanced XL & 1 & 1 & 1 & 1 & 1 & 1 \\
\hline Maxwell 16 & 1 & 1 & 1 & 1 & 1 & 1 \\
\hline QIAcube & 1 & 1 & 1 & 1 & 1 & 1 \\
\hline
\end{tabular}

a): The number in the parenthesis is the number of partial profile $(\mathrm{s})$. 
料, MW16では 0 試料, QC では 8 試料であった. また，デニムは，DNA 溶液に混入した場合に， PCR を阻害する可能性があるが16,17)，血痕（デニ ム布）については，いずれの装置でも，3名分の計 15試料のすべてから, 全座位が検出された。一方, 希釈血痕（デニム布）については，3名分の計 15 試 料のうち, 全座位が検出されたのは, AMEでは15 試料, EZ1 XL では14試料, MW16では 6 試料, QC では14試料であった（Table 2). なお，試料を 付着させてないデニム布について，各装置により抽 出操作を行い, 得られた抽出液に, コントロール DNA である9947A DNA を混合してSTR 型検査を 行ったところ, 抽出液 $9 \mu \mathrm{l}$ を用いた場合, いずれ の装置についても，9947A DNAのSTR 型がすべ て検出され，PCR 阻害は観察されなかった。しか し，この抽出液 $20 \mu \mathrm{l}$ を用いた場合，EZ1 XL およ び QCでは，PCR 阻害が観察されなかったが， AMEでは，9947A DNA のピークが低下し，一部 の座位が検出されず，また，MW16では，すべての 座位が閾値 $150 \mathrm{RFU}$ 以上であったものの，一部の 座位に抢いて，PCR 阻害によると思われるピーク の大きな低下が認められた（Fig. 2).

2 毛根部および毛幹部からの DNA 抽出, ならび にSTR 型検査およびミトコンドリアDNA 検査 毛根部から各装置で抽出したDNA 溶液につい て，核DNA およびミトコンドリアDNAの定量值 は, いずれも, EZ1 XL, AME, QC, MW16の順に低 くなる傾向が観察された。一方, 毛幹部から各装置 で抽出したDNA 溶液について，ミトコンドリア DNA の定量值は, AME で顕著に高く, 以下 $\mathrm{QC}$, EZ1 XL，MW16の順に低くなる傾向が観察された (Fig. 3).

毛根部からのSTR 型検査については，3名分の 各 5 試料のうち, それぞれ 1 試料から検査を行い, いずれの装置で抽出した DNA 溶液を用いても，す べての座位が検出された（Table 2).

毛根部からのミトコンドリア DNA 検査では，い ずれの試料についても，2,000 copies を PCR 増幅 したところ, QCでは, 一部の試料で, 薄いバンド が観察されたものの，それ以外の装置については， $\mathrm{A}, \mathrm{C}$ 領域ともに，良好なバンドが観察された

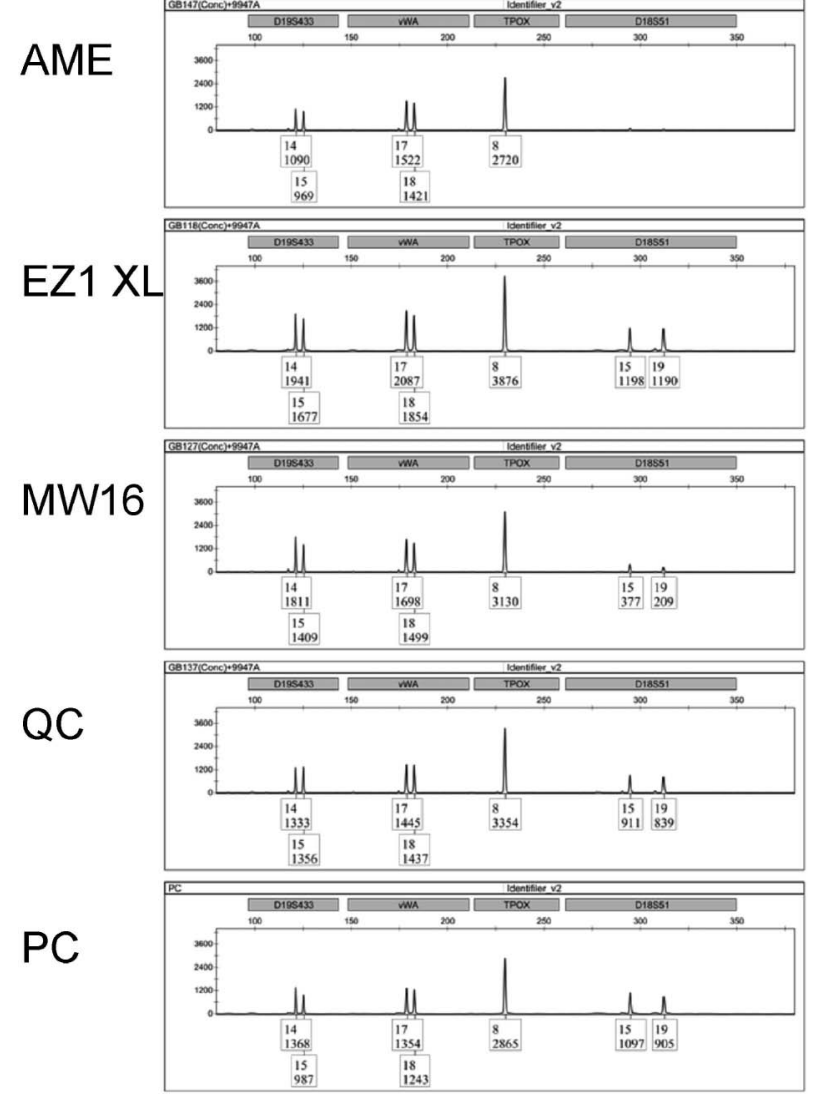

Fig. 2 Effect of denim extract on the PCR amplification of STR typing. Only denim cloth was processed by automated extraction instruments to get $50 \mu \mathrm{l}$ of denim extract. Twenty microliters of the denim extract was dried up, and $10 \mu \mathrm{l}$ of 9947A DNA $(0.1 \mathrm{ng} / \mu \mathrm{l})$ of Identifiler kit was added. From this mixture, STR typing was then performed. Only the yellow panels (NED labeled profiles) are shown. The inhibition of the PCR amplification was slightly observed for AutoMate Express (AME) and Maxwell 16 (MW16), but not for EZ1 Advanced XL (EZ1 XL) and QIAcube (QC). As a positive control, only $10 \mu \mathrm{l}$ of 9947A DNA was amplified (PC).

(Fig. 4).

毛幹部については，ミトコンドリアDNAの定量 值が 500 copies / $\mu$ 以上の試料では 2,000 copiesを, また， 500 copies $/ \mu \mathrm{l}$ 未満の試料では $4 \mu \mathrm{l}(2,000$ copies未満）を，それぞれPCR 増幅した。 その結 果, C 領域については, 2,000 copies 未満を PCR 増幅した試料では, バンドが薄くなりやすい傾向を 
(a) Hair root

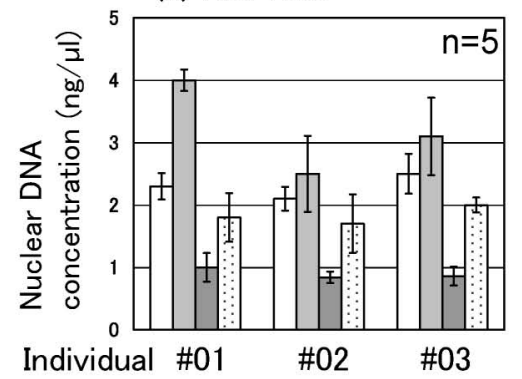

(c) Hair shaft

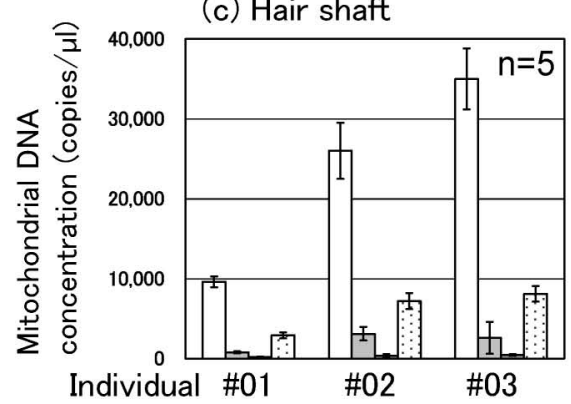

(b) Hair root

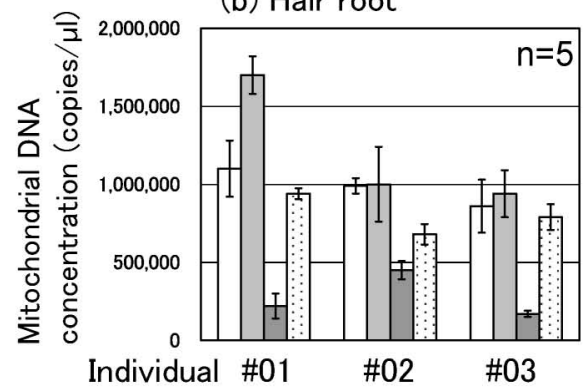

AutoMate Express

EZ1 Advanced XL

Maxwell 16

QIAcube

Fig. 3 The concentrations of nuclear DNA and/or mitochondrial DNA obtained from hair root (a, b), and hair shaft (c). From 3 individuals, 35 hair samples were plucked from each head. Each of the hairs was cut to obtain approximately $5 \mathrm{~mm}$ of hair root, and approximately $20 \mathrm{~mm}$ of hair shaft adjacent to the hair root. The 35 samples of the hair root or the hair shaft were lysated in 7 tubes in lysis buffer consisting of ATL buffer, proteinase K, and dithiothreitol (DTT). The lysate of the hair root or the hair shaft was combined together, and then separated to 35 aliquots of $100 \mu \mathrm{l}$ lysate. The aliquot was mixed with $400 \mu \mathrm{l}$ of PrepFiler lysis buffer for AutoMate Express, $100 \mu \mathrm{l}$ of ATL buffer for EZ1 Advanced XL, $500 \mu \mathrm{l}$ of Promega's Lysis buffer for Maxwell 16, and $200 \mu \mathrm{l}$ of ATL buffer for QIAcube. DNA was extracted by following the suppliers' instructions. The concentration of nuclear DNA was quantified by real-time PCR assay using human specific sequence of D17Z1 locus only from the hair root samples. The concentration of mitochondrial DNA was quantified by real-time PCR assay using the $\mathrm{C}$ region of hyper variable region 1 (HV1) of mitochondrial DNA from the hair root and the hair shaft samples.

示したが，2,000 copiesをPCR 増幅した試料で は, EZ1 による個人\#03の 1 試料を除いて, バンド の濃さは良好で, 安定していた。一方, A 領域に ついては，2,000 copies 未満を PCR 増幅した試料 では，薄いバンドを示すものが多く，また，2,000 copies をPCR 増幅した試料であっても，C領域と 比較して全体的に薄くなり, バンドの濃さは, 装置 間, 試料間で, 大きな差が観察された。 2,000 copies を PCR 増幅した試料について, A 領域のバン ドをさらに観察すると, AMEでは, 全体的に, A 領域のバンドが，他の装置よりも，薄くなりやすい 傾向を示していた. EZ1 XL では, C 領域で薄いバ ンドを示した個人\#03の 1 試料は，A 領域でも薄い
バンドを示していたが，それ以外の試料では，極端 に薄いバンドのものはなかった。また，MW16およ び QCでは，極端に薄いバンドのものはなかった (Fig. 4).

毛根部および毛幹部から各装置で抽出した 3 名分 の各 5 試料のうち，それぞれ 1 試料について, PCR 増幅，シーケンス反応抢よび塩基配列解析を 行った.いずれの試料についても，ミトコンドリア DNA 検査が最後まで実施可能であった。しかし， 毛幹部では, 毛根部よりも, PCR 増幅サイズが約 440塩基の A 領域，および約450塩基の D 領域にお いて，バンドが全体的に薄かったため，塩基配列解 析においてピークが低くなり，ノイズの影響を受け 


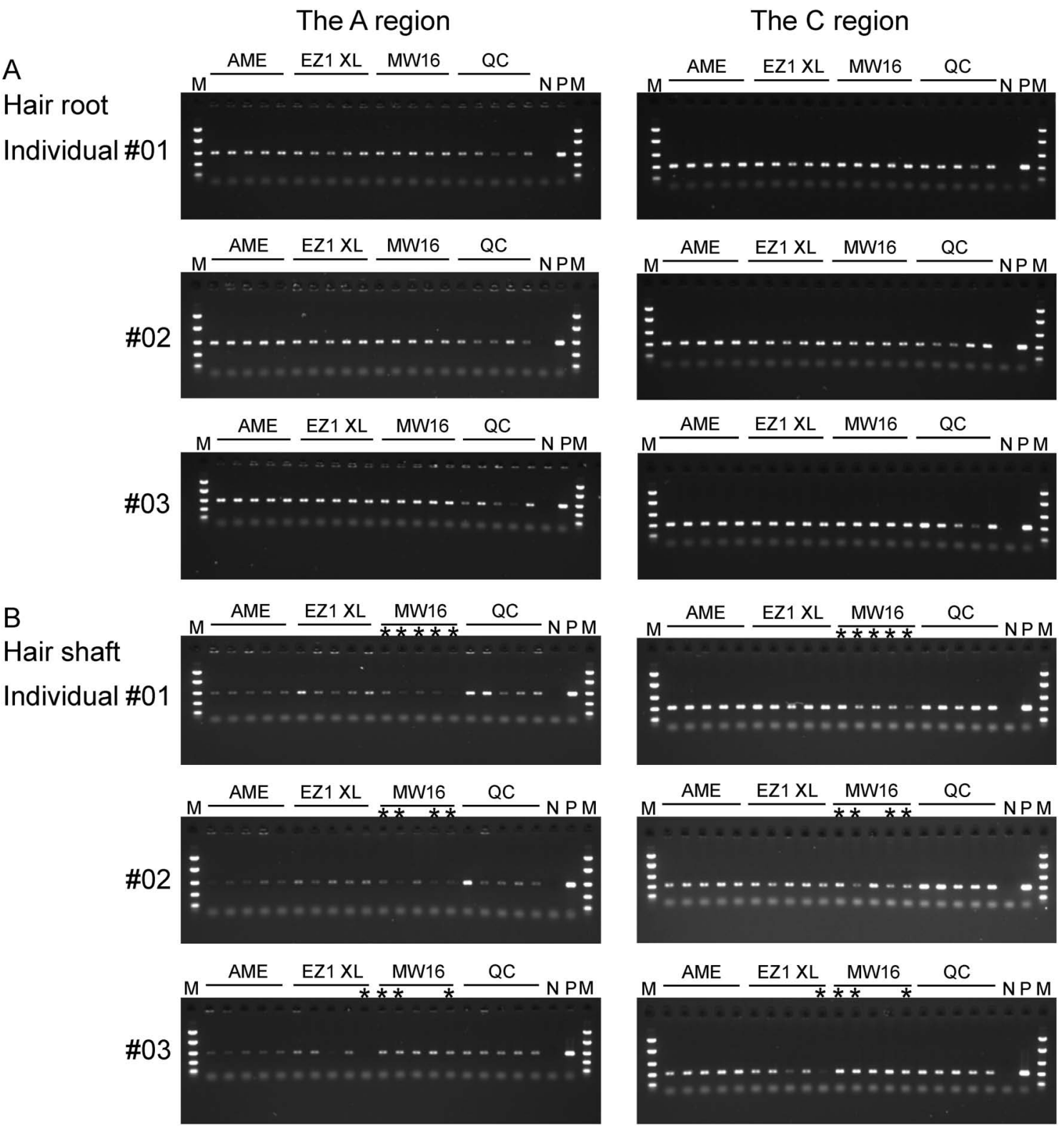

Fig. 4 Amplification of the A and the C regions in hyper variable region 1 (HV1) of mitochondrial DNA. DNA was obtained by automated extraction instruments from hair root (A) and hair shaft (B). The concentration of mitochondrial DNA was quantified by real-time PCR assay using the $\mathrm{C}$ region. For PCR amplification, 2,000 copies of mitochondrial DNA was used for the samples $>500$ copies $/ \mu 1$. Four microliters (less than 2,000 copies) of mitochondrial DNA was used for the samples $<500$ copies $/ \mu 1(*)$.

M: size marker containing fragments of 100, 250, 500, 1,000 and 2,000 base pairs, AME: AutoMate Express, EZ1 XL: EZ1 Advanced XL, MW16: Maxwell 16, QC: QIAcube, N: negative control, P: positive control.

やすい傾向にあった。とりわけ，AMEでは，この 傾向が顕著であった。ただし，AMEにより毛幹部 から抽出した DNA 溶液であっても，鋳型量を 2,000 copies から10,000 copiesに増やした場合に は，バンドが濃くなったため，塩基配列解析におい
てもピークが高くなり，ノイズの影響はほとんど受 けなくなった。

\section{考 察}

各種法科学試料から，4 種類の自動抽出装置によ 
り, DNA を抽出した。血痕 (サラシ布), 希釈血 痕 (サラシ布), 血痕 (デニム布), 希橎血痕 (デニ 厶布）および毛幹部からの DNA 抽出では, AME を用いた場合, 他の装置と比較して, 高い DNA 定 量值が得られやすい傾向を示した. しかし，デニム 布からの抽出液 $9 \mu \mathrm{l}$ を用いた場合には, いずれの 装置でも PCR 阻害は観察されなかったものの, 20 $\mu \mathrm{l}$ を用いた場合には，AME およびMW16では， PCR 阻害を受けることが示唆された.

AMEの製造元の情報では, PrepFiler forensic DNA extraction kit では, 磁気ビーズの粒径が, 他 の標準的な DNA 抽出キットより小さく, DNA 抽 出効率が向上しているとされている ${ }^{18)}$. た, これ まで, PrepFiler forensic DNA extraction kit を手作 業で用いた場合, フェノール・クロロホルム法, DNA IQ System, EZ1 DNA Investigator kit (BioRobot EZ1), および QIAamp DNA Micro kit と比較して, 抢抢むね, 同等以上の高い DNA 定量 值が得られたと報告されている8). しかし, AME では, 磁気ビーズの粒径が小さいため, DNA 抽出 効率が向上するかわりに，デニム布からの抽出液を コントロール DNA に添加する実験で示されたよう に, PCR 阻害物質の除去が不十分である可能性が 考えられる。したがって, AMEは, PCR 阻害物 質を含む試料からの DNA 抽出には, 慎重に用いる 必要があると考えられる。

毛髪からの DNA 抽出では, 毛髪 1 本ずつに含ま れるDNA 量が異なること, ならびに AME, EZ1 XL および MW16の各キットに含まれる試薬では, 溶解が不十分であったため, 必要な本数の毛根部お よび毛幹部を, 溶解力の優れた ATL bufferに, QIAgen proteinase K およびDTTを加える条件で 溶解させ, 得られた溶解液を混合した後, 分注して 各抽出装置によるDNA 抽出に用いた.

毛幹部に含まれるDNA は高度に分解してお り 19)，DNA が分解した試料からのミトコンドリア DNA 検査では, STR 型検査の結果20,21) と同様に, PCR 増幅サイズが短いほど, 検出されやすいと報 告されている ${ }^{22,23)}$. 今回, 毛幹部からのミトコンド

リア DNA 検査では, PCR 増幅サイズが約230塩基 の C 領域を用いて定量したため, C 領域では, ほ
とんどの試料でコピー数が適正となり，良好なバン ドが観察されたが，PCR 増幅サイズが約440塩基の A 領域では15), DNAの分解により, 鋳型として機 能するコピー数が不足し, 全体的にバンドが薄くな ったと考えられる.とりわけ，AMEでは，この傾 向が強かったことから, AMEは, 毛幹部からの DNA 抽出に打いて, 他の 3 種類の装置と比較し て, 大きいサイズの DNA 断片よりも, 小さいサイ ズの DNA 断片を, 回収しやすい可能性が示唆され る. また, AMEでは, 塩基配列解析において, ノ イズの少ない結果を得るために, 鋳型量を 2,000 copies から10,000 copiesに増やす必要があった。この ことから, AMEにより毛幹部から抽出した DNA 溶液に含まれる検査に必要なミトコンドリア DNA 濃度は, Fig. 3 に示したほど高くないと考えられ る.

今回, 検討した自動抽出装置のうち, QC は, あ らかじめ複数の試薬を, 専用のボトルに移した上 で, 装置にセットする必要があるので, 操作が煩雑 であり, MW16は, 今回の検討により抽出効率が低 いことが示されたので, 法科学試料からの DNA 抽 出には, AME および EZ1 XL が適していると考え られる. 今回検討した試料では, 扔打むね $\mathrm{AME}$ は, EZ1 XLよりも高い DNA 定量值が得られやす い傾向を示した。しかし, AMEについては, PCR 阻害物質の除去が不十分である可能性があるので, 定量值の低いDNA 溶液を濃縮して用いる場合に は，注意が必要である。また，AMEでは，毛幹部 からの DNA 抽出に抢いて, ミトコンドリアDNA の定量值が，EZ1 XLよりも安定して得られたが， ミトコンドリア DNA 検査では, EZ1 XLよりも多 いコピー数の鋳型が必要であったことから，フラグ メントサイズの小さい DNA 断片が優先的に回収さ れる可能性が考えられた。 今後, 陳旧血痕などの DNA が分解した試料について，さらに検討する必 要があると考えられる。

\section{文 献}

1) Scherczinger, C. A., Bourke, M. T., Ladd, C. and Lee, H. C.: DNA extraction from liquid blood using QIAamp. J. Forensic Sci. 42, 893-896 
(1997).

2) Greenspoon, S. A., Ban, J. D., Sykes, K., Ballard, E. J., Edler, S. S., Baisden, M. and Covington, B. L.: Application of the BioMek 2000 Laboratory Automation Workstation and the DNA IQ System to the extraction of forensic casework samples. J. Forensic Sci. 49, 29-39 (2004).

3) Frégeau, C. J., Lett, C. M., Elliott, J., Yensen, C. and Fourney, R. M.: Automated processing of forensic casework samples using robotic workstations equipped with nondisposable tips: contamination prevention. J. Forensic Sci. 53, 632-651 (2008).

4) Montpetit, S. A., Fitch, I. T. and O'Donnell, P. T.: A simple automated instrument for DNA extraction in forensic casework. J. Forensic Sci. 50, 555-563 (2005).

5) Anslinger, K., Bayer, B., Rolf, B., Keil, W. and Eisenmenger, W.: Application of the BioRobot EZ1 in a forensic laboratory. Legal Medcine. 7, 164-168 (2005).

6) Kishore, R., Reef Hardy, W., Anderson, V. J., Sanchez, N. A. and Buoncristiani, M. R.: Optimization of DNA extraction from low-yield and degraded samples using the BioRobot EZ1 and BioRobot M48. J. Forensic Sci. 51, 1055-1061 (2006).

7) Krnajski, Z., Geering, S. and Steadman, S.: Performance verification of the Maxwell 16 Instrument and DNA IQ Reference Sample Kit for automated DNA extraction of known reference samples. Forensic Sci. Med. Pathol. 3, 264269 (2007).

8) Brevnov, M. G., Pawar, H. S., Mundt, J., Calandro, L. M., Furtado, M. R. and Shewale, J. G.: Developmental validation of the PrepFiler Forensic DNA Extraction Kit for extraction of genomic DNA from biological samples. J. Forensic Sci. 54, 599-607 (2009).

9）藤井宏治, 北山哲史, 中原弘明, 水野なつ 子，吉田日南子，関口和正 : STR 型検査のため
の口腔内細胞採取キットの比較. 法科学技術.

14, 55-60 (2009).

10） GEヘルスケアサイエンス： EasiCollect. (2007).

11）中原弘明, 藤井宏治, 水野なつ子, 吉田日南 子，笠井賢太郎：法生物学的試料由来の DNA に対する定量法の検証. 法科学技術. 12，13-26 (2007).

12) Nakahara, H., Sekiguchi, K., Imaizumi, K., Mizuno, N. and Kasai, K.: Heteroplasmies detected in an amplified mitochondrial DNA control region from a small amount of template. J. Forensic Sci. 53, 306-311 (2008).

13）吉田日南子, 高橋健一, 笠井賢太郎 : $\mathrm{AmpF}$ / STR Identifiler PCR amplification kit の法科学試 料への応用に関する検討. 科警研報告. 57，4956 (2006).

14）笠井賢太郎, 吉田日南子, 水野なつ子, 中原 弘明, 藤井宏治, 関口和正: 証拠資料からの DNA 型検査法（第 3 報）。科警研報告．58，3236 (2007).

15) Sekiguchi, K., Imaizumi, K., Matsuda, H., Mizuno, N., Yoshida, K., Senju, H., Sato, H. and Kasai, K.: MtDNA sequence analysis using capillary electrophoresis and its application to the analysis of MtDNA in hair. Jpn. J. Sci. Tech. Iden. 7, 123-130 (2003).

16) Del Rio, S. A., Marino, M. A. and Belgrader, P.: PCR-based human leukocyte antigen (HLA) DQ alpha typing of blood stained light and dark blue denim fabric. J. Forensic Sci. 41, 490-492 (1996).

17) Larkin, A. and Harbison, S.: An improved method for STR analysis of bloodstained denim. Int. J. Legal Med. 112, 388-390 (1999).

18） アプライドバイオシステムズ : PrepFiler Forensic DNA Extraction キット (2008).

19）松田秀明, 今泉和彦, 窪田聡, 宮坂祥夫, 吉 野峰生, 瀬田季茂: 毛幹部加らの DNA 抽出法 に関する技術的な検討. 科警研報告. 50，23-28 (1997). 
20) Yoshida, K., Sekiguchi, K., Kasai, K., Sato, H., Seta, S. and Sensabaugh, G. F.: Evaluation of new primers for CSF1PO. Int. J. Legal Med. 110, 36-38 (1997).

21) Fujii, K., Senju, H., Yoshida, K., Sato, H. and Kasai, K.: A new procedure for the multiplex PCR amplification of TH01, CSF1PO and TPOX loci with amall amplicon lengths. Jpn. J. Sci. Tech. Iden. 6, 129-134 (2002).

22) Gabriel, M. N., Huffine, E. F., Ryan, J. H.,
Holland, M. M. and Parsons, T. J.: Improved MtDNA sequence analysis of forensic remains using a "mini-primer set" amplification strategy. $J$. Forensic Sci. 46, 247-253 (2001).

23) Eichmann, C. and Parson, W.: 'Mitominis': multiplex PCR analysis of reduced size amplicons for compound sequence analysis of the entire mtDNA control region in highly degraded samples. Int. J. Legal Med. 122, 385-388 (2008). 